\title{
PENGARUH INKLUSI KEUANGAN DAN LITERASI KEUANGAN TERHADAP KINERJA UMKM PADA MASA PANDEMI COVID 19 (Studi kasus pada UMKM Kabupaten Malang)
}

\author{
Safira Nindy Febriana ${ }^{1}$, Muhammad Sulhan² \\ Fakultas Ekonomi, Universitas Islam Negri Maulana Malik Ibrahim Malang \\ email: nazrillasafira99@gmail.com
}

\begin{abstract}
ABSTRAK
Tujuan penelitian ini untuk mengetahui pengaruh Inklusi Keuangan dan Literasi Keuangan Terhadap Kinerja UMKM pada masa pandemi Covid -19 di daerah Kabupaten Malang. Metode penelitian ini yang digunakan adalah penelitian kuantitatif. Sumber data yang digunakan yaitu data primer dan data sekunder yang diperoleh dari penyebaran kuesioner. Populasi pada penelitian ini adalah UMKM di Kabupaten Malang dengan jumlah 100 responden. Teknik pengambilan sampel menggunakan metode probability sampling dengan cara sampling jenuh. Data dalam penelitian ini diolah dengan SEM berbasis PLS. Berdasarkan hasil penelitian dapat disimpulkan bahwa kedua variabel bebas yaitu inklusi keuangan dan literasi keuangan memiliki pengaruh positif terhadap kinerja UMKM pada masa pandemic Covid-19 di Kabupaten Malang.
\end{abstract}

Kata Kunci: Inklusi Keuangan, Literasi Keuangan, Kinerja UMKM.

\section{ABSTRACT}

The purpose of this study was to determine the effect of Financial Inclusion and Financial Literacy on MSME Performance during the Covid -19 pandemic in the Malang Regency area. This method used is quantitative research. Sources of data used are primary data and secondary data obtained from the distribution of questionnaires. The population in this study was MSMEs in Malang Regency with a total of 100 respondents. The sampling technique used the probability sampling method by means of saturated sampling. The data in this study was processed using the Validity test with the help of the PLS version 3. Based on the results of the study, it can be concluded that the two independent variables, namely financial inclusion and financial literacy, have a positive influence on the performance of MSMEs during the Covid19 pandemic in Malang Regency.

Keywords: Financial Inclusion, Financial Literacy, MSME Performance.

\section{PENDAHLUAN}

Negara Indonesia merupakan salah satu Negara yang memiliki kekayaan akan sumber daya alam yang sangat menjanjikan bagi kehidupan manusia. Dengan hal ini membuktikan bahwa manusia tidak dapat hidp tanpa adanya sumber daya alam. Manusia memiliki ketergantungan pada sumber daya alam yang memiliki pengaruh pada pola pemanfaatan serta dalam pengelolaan sumber daya alam yang ada. Dengan adanya kekayaan alam, budya serta sumber daya alam sering kali diabaikan serta tidak dilihat sebagai modal utama dalam pembangunan ekonomi. Dengan adanya ekonomi kreatif menjadikan lonjakan pada sektor jasa yang saat ini mengalami perkembangan. Dengan adanya kreatifitas dapat dikonversi yang menjadikan komoditas yang memiliki nilai bisnis yang tinggi (Mustaqim, 2018).

Literasi keuangan merupakan salah satu pemahaman yang komprhensif dan mendalam yang berkaitan dengan pengelolaan keuangan secara personal atau juga dapat disebut sebagai keluarga yang dapat 
membuat seseorang memiliki kekuasaan, pemahaman, dan juga memiliki keyakinan penuhdalam membuat keputusan keuangan yang akan diambil. Seperti yang telah diungkapkan oleh Vitt et al (2000) mengungkapkan bahwa pendidikan kiterasi ekuanagn merupakan suatu kemampuan dalam membaca, mengelola, menganalisisi, serta bagaimana cara berkomunikasi yang berkaitan dengan kondisi keuangan yang berpengaruh dengan kesejahteraan. Dalam literasi keuangan mencakup dengan berbagai kemampuan dalam memilih suatu kebutuhan keuangan dan perencaan keuangan di masa yang akan datang. Dapat memahami suatu kejadian atau peristiwa yang dapat mempengaruhi keputusan keuangan dalam kesehariannya, salah satunya peristiwa dalam perekonomian umum. Dalam kehidupan sehari-hari pendidikan literasi keuangan sangat berperan penting bagi kehidupan manusia. Dari beberapa kasus menunjukkan bahwa dalam mengambil keputusan dengna tepat dalam hal ini dapat menentukan kesejahteraan manusia di masa yang akan datang. Dalam halnya setiap manusia memerlukan dalam pembekalan dengan pendidikan literasi keuangan yang baik serta terencana.

Inklusi keuangan menjadi salah satu topik yang hangat untuk dibincangkan terutama dalam pembangunan global, secara garis besar iklusi keuangan dianggap sebagai suatu alat kebijakan yang mendorong dalam pertumbuhan serta stabilitasan dalam mengurangi kemiskinan. Sedangkan definisis inklusi keuangan menurut Word Bank dan European Commision yakni suatu bentuk kegiatan penyuluhan dengan tujuan menghilangkan segala hambatan baik dalam bentuk harga maupun non harga terhadap suatu akses masyarakat dalam memanfaatkan maupun dalam penggunaan layanan jasa keuangan (Soederberg, 2013).

Kinerja merupakan ukuran dalam mencapai suatu keberhasilan pada sebuah entitas usaha dalam mencapai suatu tujuan. Kinerja merupakan suatu hasil yang memiliki hubungan yang kuat pada tujuan yang strategis organisasi, kepuasan konsumen, serta dapat memberikan kontribusi pada ekonomi (Abidoun, 2015). Terdapat beberapa faktor yang dapat mempengaruhi kinerja UMKM, seperti dalam penelitian yang telah dilakukan oleh Aribawa (2016), didalam penelitiannya mengatakan bahwa telah diketahui terdapat literasi keuangan terhdap kinerja dan jga keberlanjutan UMKM.

Usaha Mikro Kecil dan Menengah (UMKM) memiliki peran yang sangat penting secara signifikan bai pembangunan bagi suatu Negara tertentu (Audretsch, Van der Horst, Kwaak, dan Thurik, 2009; Carrter dan Jones-Evans, 2006). Sedangkan dilihat dari spesifik, keberadaan UMKM sendiri dapat dipercaya serta dapat memberikan kontribusi terhadap meminimalisisrka kemiskinan pada masyarakat dengan cara membangun lapangan kerja (Carrer dan Klomp, 1996; Adomoko, Danso, dan Damoah, 2016). Dengan hal ini Kementerian Keuangan Republik Indonesia (2015), pemerintah memberikan kredit sebagai modal utama UMKM yang telah terlibat dalam kegiatan dalam mendukung ekspor, dengan memberikan nilai tingkat bunga yang rendah dibandingkan dengan dengan nilai bunga komersial yang secara umum, dari pengungkapan diatas melalui Paket Kebijakan Ekonomi Tahap IV.

Maka dengan hal ini agar virus tidak semakin menyebar luas maka pemerintah di berbagai Negara yang juga termasuk Indonesia menerapkan kebijakan Pembatasan Sosial Bersekala Besar (PSBB) guna meminimalisirkan pentebaran Virus Covid 19 semakin meluas. Selain itu juga menciptakan krisis kesehatan global, serta upaya supresi dan mitigasi pada pandemi Covid-19 juga menimbulkan disrupsi yang kuat pada tatanan perdagangan internasional. Di lihat dari sisi penawaran (supply), kebijakan lockdown serta working from home mengakibatkan berkurangnya tenaga kerja yang terlibat dalam aktifitas produksi pada masa pendemi. Dengan kebijakan yang telah ditetapka oleh pemerinth tersebut, maka tidak lain dapat menyebabka terdampaknya penurunan omzet pada pelaku UMKM di Kabupaten Malang saat diberlakukannya kebijakna PSBB. Dengan hal ini menyebabkan para pedagang mengalami penurunan pada jumlah pembeli. Dengan hal ini sejak tersebarnya Virus Covid 19 dengan menurunnya tingkat pembeli maka pelaku UMKM mengalami penurunan. Terdapat pelaku UMKM yang sampai saat ini masih bertahan meski adanya kebijakan Pembatasan Sosial Berskala Besar (PSBB) yakni UMKM yang menyediakan kebutuhan pokok seperti ssembako, sayur-sayuran, dan rumah makan yang menjual dengan harga relatif murah. Selain itu, terdapat pelaku UMKM yang sangat terdampak Covid 19 yakni plaku UMKM yang bergerak dibidanga makanan dan minuman. 
Berdasarkan hasil Survei Nasional Literasi keunangan dan Literasi Keuangan (SNLIK) yang telah dipaparkan oleh Ototitas Jasa Keuangan (OJK) tahun 2019, menyatakan bahwa tingkat Literasi Keuangan dan Inklusi Keuangan Tahun 2019 masing-masing mencapai nilai 38,03\% dan 76,19\%. Dengan adanya nilai presentase tersebut dapat memberikan kesenangan tersendiri, karena dengan peningkatan pada presentase tersebut telah berhasil dalam melampaui target yang telah ditetapkan oleh pemerintah dalam peraturan presiden No. 82 tahun 2016 yeng berisikan tentang Strategi Nasional Keuangan Inklusif (SNKI), dalam peraturan tersebut telah ditetapkan dengan target nilai presentase pada Inklusi Keuangan sebesar $75 \%$, sedangkan target nilai presentase pada Literasi Keuangan yang telah ditentukan dalam Peraturan Presiden No. 50 Tahun 2017 yang berisikan tentang Strategi Nasional Perlindungan Konsumen dengan target terbesar 35\% juga telah terlampaui. Berdasarkan angka tersebut terdapat peningkatan yang cukup signifikan dari berbagai survey sebelumnya yang berada di tahun 2016, dimana terdapat tingkat pemahaman keuangan pada masyarakat dengan nilai presentase sebesar $8,33 \%$ serta dalam peningkatan akses terhadap produk serta layanan jasa keuangan dengan nilai presentase sebesar 8,39\%.

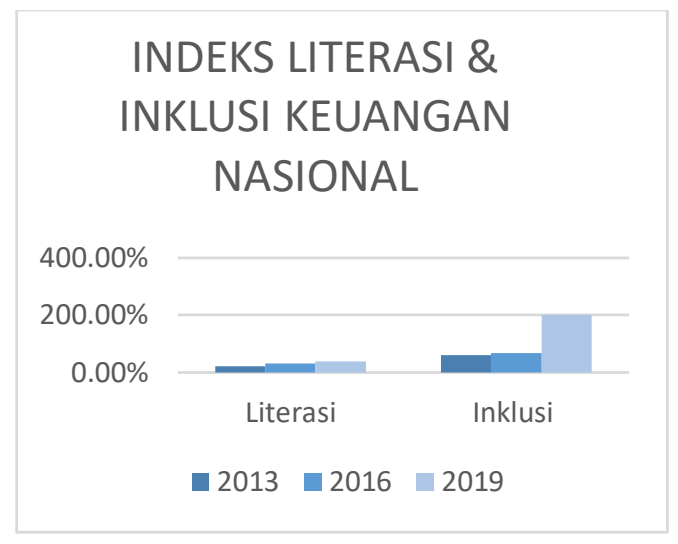

Gambar 1.1 Indeks Literasi dan Inklusi Keuangan tahun 2019

Sumber: OJK, 2019

Survei tersebut telah ketiga kalinya dilakukan oleh OJK yang melibatkan sebanyak 12.773 responden dari 34 provinsi dan 67 kabupaten/kota yang mencakup seluruh sektor jasa keuangan yang berada dalam pengawasan OJK, mulai dari sektor Pasar Modal, sektor Perbankan, hingga pada Industri Keuangan NonBank (IKNB) seperti Lembaga Pembiayaan, Dana Pensiun, Pegadaian, Perasuransian, serta LJK formal lainnya. Berdasarkan pengukuran Survei Nasional Literasi keunangan dan Literasi Keuangan (SNLIK) tahun 2019 menggunakan indikator yang sama dengan 2 survey yang sebelumnya pada tahun 2013 dan tahun 2016. Berdasarkan tingkat inklusi keuangan menggunakan parameter penggunaan produk atau layanan jasa keuangan dalam satu tahun terakhir. Sedangkan untuk tingkat literasi keuangan dengan indikator keterampilan, keyakinan, sikap dan juga perilaku, serta pengetahuaan. 


\section{Jumlah UMKM dan Tenaga Kerja UMKM Kab. Malang \& Kota Malang}

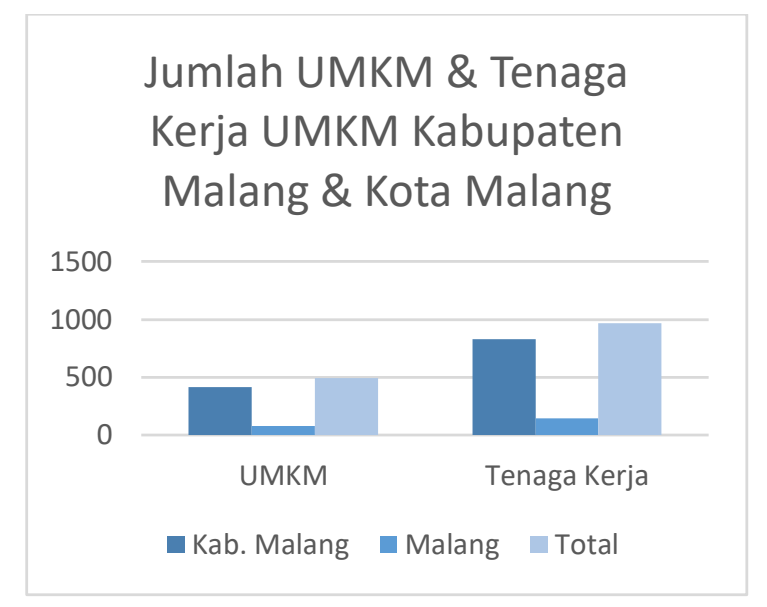

Sumber: https://muhnanangchoiruddin.blogspot.co

Dari penelitian yang telah dipaparkan oleh Poppy Alvianolita Sanistasya, Kusdi Rahardjo, Mohammad Iqbal, (2019) pada variabel independen pengukuran inklusi keuangan menggunakan indikator akses, kualitas, penggunaan, dan kesejahteraan. Sedangkan pada penelitian yang telah dilakukan oleh Bongomin (2017) pada variabel inklusi keuangan menggunakan indikator akses dan kesejahteraan. Sedangkan pada penelitian yang dilakukan oleh Yanti (2019), pada variabel inklusi keuangan menggunakan indikator kualitas, pemakaian dan kesejahteraan, serta akses.

Dari penelitian yang telah dipaparkan oleh Poppy Alvianolita Sanistasya, Kusdi Rahardjo, Mohammad Iqbal, (2019) pengukuran literasi keuangan menggunakan indikator perilaku, ketrampilan, pengetahuan, dan sikap. Pada penelitian widiyati (2018) pengukuran Literasi keuangan menggunakan indikator perilaku, sikap, dan pengetahuan. Sedangkan pada penelitian Yanti (2019) dalam pengukuran literasi keuangan menggunakan indikator asuransi, pinjaman dan tabungan, serta investasi.

Peran inklusi keuangan dan literasi keuangan sangat dibutuhkan bagi masyarakat. Pada dasarnya sektor jasa keuangan memiliki peran yang sangat penting dalam upaya meningkatkan kesejahteraan pada masyarakat serta dapat mendorong dalam pertumbuhan ekonomi secara global. Pada sektor keuangan ini terdapat peranann yang dapat dilihat dari adanya keberadaan pada trilogy pemberdayaan konsumen terdiri dari injlusi keuangan, litersi keuangan, serta dalam perlindungan pada konsumen. Pada tahun 2010 dari berbagai para pemimpin Negara yang telah bergabung pada G20 dalam forum Organisasi for Economic Cooperation and Development (OECD) menyatakan bahwa telah menetapkan integrasi dari prinsip inklusi keuangan, literasi keuangan, serta akan adanya perlindungan konsumen yang sangat penting guna untuk memperkuat sistem keuangan serta dapat meningkatkan kesejahteraan pada masyarakat (Atkison, 2013).

\subsection{Tinjauan Pustaka dan Pengembangan Hipotesis \\ Hubungan Variabel Inklusi Keuangan Terhadap Kinerja UMKM.}

Dari beberapa yang telah dipaparkan dari beberapa peneliti, hasil penelitian yang telah dilakukan oleh Riwayati (2017) menunjukkan bahwa hasil penelitiannya menunjukkan bahwa variabel inklusi keuangan dapat meningkatkan suatu perumbuhan bagi usaha kecil. Inklusi keuangan mampu membuka peluang bagi pelaku usaha yang berguna untuk mengakses pada ketersediaannya akan layanan keuangan, kesejahteraan dalam penggunaan produk dan layanan keuangan yang pada akhirnya dapat digunakkan serta juga daoat dimanfaatkan pada proses kegiatan usaha dalam meningkatkan pada pertumbuhan penjualan, pertumbuhan pada laba, modal, serta lapangan pekerjaan. 
Menurut Beck dan Demirguc - Kunt (2006), dalam penelitiannya menunjukkan bahwa dalam akses yang digunakan untuk membiayai usaha kecil dalam membangun ekonomi maka dengan hal ini untuk melakukan investasi yang produktif dalam rangka untuk membangun suatu usaha untuk memperoleh teknologi terbaru, untuk meraih daya saing serta mampu endorong dalam inovasi. Maka dari itu pada sektor informal inilah yang berasal dari peningkatan kapitalisasi bisnis inilah dapat membangun lapangan kerja serta akan mendapatkan pertumbuhan pada pendapatan dengan jangka panjang.

Dari hasil penelitian yag telah dilakukan oleh Wira Iko Putri Yanti (2019), menyatakan bahwa inklusi keuangan dapat memberikan pengaruh positif dan signifikan terhadap kinerja UMKM. Maka dengan hal ini dapat menunjukkan bahwa kinerja UMKM dapat memberikan peningkatan secara signifikan jika pelaku UMKM dapat memberikan peningkatan dalam inklusi keuangan.

\section{H1 : Inklusi Keuangan berpengaruh Positif dan Signifikan terhadap Kinerja UMKM}

\section{Hubungan Variabel Literasi Keuangan Terhadap Kinerja UMKM}

Perlunya memiliki cara yang strategis untuk meningkatkan kinerja yakni dengan salah satunya yaki adanya literasi keuangan, keyakinan serta ketrampilan dapat mempengaruhi perilaku serta sikap dalam meningkatkan suatu kualitas dalam pengambilan keputusan serta pengelolaan keunagan untuk mencapai suatu kesejahteraan, hal ini dinyatakan oleh (Ariwibawa D., 2016). Hasil penelitian yang telah dipaparkan oleh Aryo Prakoso (2020), menyatakan bahwa literasi keuangan memiliki pengaruh yang signifikan terahadap kinerja UMKM.

H2 : Literasi Keuangan berpengaruh Positif terhadap Kinerja Keuangan.

\section{Hubungan Variabel Inklusi Keuangan dan Literasi Keuangan Terhadap Kinerja UMKM}

UMKM merupakan suau usaha produktif yang dimiliki oleh perorangan maupun badan usaha yang telah memenuhi kriteria sebagai usaha mikro. Dalam usaha ini memiliki berskala kecil serta bersifat padat akan karya serta juga melibatkan sebagai suatu aktifitas eknomi maupun bisnis. Baik dilihat dari segi teknologi, investasi, manajemen, maupun perlindungan hak cipta. Menurut Rudjito, UMKM merupakan suatu usaha yang memiliki peran penting bagi perekonomian suatu Negara. Baik dilihat dari sisi terbukanya lapangan kerja atau dari sisi jumlah suatu usaha yang didirikannya.

Usaha Mikro Kecil dan Menengah (UMKM) secara umum sering terlambant dalam perkembangan. Hal ini disebabkan karena adanya permasalahan pada konvensional karena tidak tuntas terselesaikannya, seperti halnya pada masalah terhadap kapasitas SDM, pembiayaan, pemasaran, pembiayaan dan jga terdapat berbagai masalah lainnya yang bersangkutan dengan pengelolaan usaha, hal ini mimicu UMKM dalam persaingan dengan perusahaan-perusahan besar (Abor dan Quartey, 2010). Menurut penelitian yang dilakukan oleh Manurung dan Barlian (2012), yang berisikan UMKM yang berkaitan di industry kreatif cederung memiliki orientasi yang berjangka pendek dalam mengambil suatu keputusan terhadap bisnis yang dijalankanya. Dari penjelasan tersebut terlihat tidak memiliki konsep inovasi yang berkelnjutan serta aktivitas inti didalam bisnis yang kompeten dan pada akhirnya, pengembangan UMKM dengan kinerja jangka panjang yang bergerak pada industry kreatif cenderung tidak akan terarah dengan baik.

Dalam akses keuangan dan kesejahteraan merupakan indikator yang banyak dugunakan dalam mengukur pada tingkat inklusi keuangan. Dengan adanya pemahaman pada masyarakat yang berkaitan degan produk dan layanan jasa keuangan dapat meningkatkan suatu kepercayaan pada masyarakat dalam menggunakan produk dan layanan jasa keuangan secara efektif. Semakin mudah dalam mengakses keuangan serta terlindungnya dalam bertransaksi pada lembaga keuangan yang ditunjang dengan adanya sikap literait yang dimilikinya, maka akan membuat seseorang tersebut dapat menggunakan layanan jasa keuangan yang sesuai dengan apa yang dibutuhkan serta kemampuannya dalam meningkatkan kesejahtteraan (Sanistasya, 2019., \& Yanti, 2019.)

H3 : Inklusi Keuangan dan Literasi Keuangan berpengaruh Positif terhadap Kinerja UMKM 


\subsection{Model Penelitian}

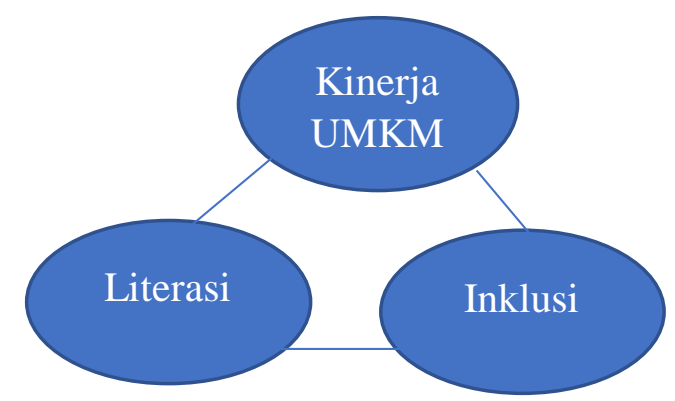

Sumber: dikembangkan untuk studi reset ini, 2021.

\section{Metode Penelitian}

Populasi yang digunaka dalam penelitian ini adalah seluruh pelaku maupun pemilik Usaha Mikro, Kecil, Menengan (UMKM) yang berrada di Kabupaten Malang dengan jumlah 100 responden. Teknik yang digunakan dalam pengamnbilan sampel adalah metode Probability Sampling. Data penelitian yang digunakan data primer dan data skunder. Dengan metode pengumpulan data menggunakan mendia penyebaran kuesioner dan didapatkan dari jurnal, artikel, buku, media internet yang berkaitan dengan topic dari penelitian.

Pertanyaan-pertanyaan yang ada pada kuesioner skala Likert yang menghasilkan jawaban sangat setuju hingga jawaban sangat tidak setuju dengan rentang nilai (Sugiyono, 2018). Definisi operasional inklusi keuangan adalah : a) Dimensi pertanyaan, b) Dimensi kesejahteraan. Dalam Peraturan Presiden Republik Indonesia Nomor 82 Tahun 2016 Inklusi keuangan merupakan suatu kondisi dimana dalam setiap anggota masyarakat memiliki akses terhadap berbagai layanan keuangan formal yang berkualitas, tepat waktu, lancar, dan aman dengan biaya terjangkau sesuai dengan kebutuhan dan kemampuan masing-masing. Definisi operasional literasi keuangan adalah: a) Dimensi Pengetahuan, b) Dimensi perilaku, c) Dimensi sikap. Berdasarkan Peraturan (Otoritas Jasa Keuangan, 2016) Nomor 76/POJK.07/2016 literasi keuangan adalah pengetahuan, keyakinan dan keterampilan yang mempengaruhi sikap dan perilaku untuk meningkatkan kualitas pengambilan keputusan dan pengelolaan keuangan dalam rangka mencapai kesejahteraan.Definisi operasional kinerja UMKM adalah: a) Dimensi probabilitas, b) Dimensi petumbuhan ekonomi, c) Dimensi pertumbuhan jumlah pegawai. Menurut Undang Undang Nomor 20 Tahun 2008, Usaha Mikro, Kecil dan Menengah (UMKM) merupakan cabang dari perkembangan industri kreatif dalam perekonomian setiap negara. 


\section{Hasil dan Pembahasan}

Table 1.1 Uji Validitas Konvergen

\begin{tabular}{|c|c|c|c|}
\hline Variabel & Indikator & $\begin{array}{l}\text { Loading } \\
\text { Factor }\end{array}$ & Keterangan \\
\hline \multirow{6}{*}{ X1 } & $\mathrm{X} 1.1$ & 0.836 & Valid \\
\hline & $\mathrm{X} 1.2$ & 0.850 & Valid \\
\hline & $\mathrm{X} 1.3$ & 0.806 & Valid \\
\hline & $\mathrm{X} 1.4$ & 0.824 & Valid \\
\hline & $\mathrm{X} 1.5$ & 0.816 & Valid \\
\hline & $\mathrm{X} 1.6$ & 0.739 & Valid \\
\hline \multirow{9}{*}{$\mathrm{X} 2$} & $\mathrm{X} 2.1$ & 0.778 & Valid \\
\hline & $\mathrm{X} 2.2$ & 0.739 & Valid \\
\hline & $\mathrm{X} 2.3$ & 0.806 & Valid \\
\hline & $\mathrm{X} 2.4$ & 0.753 & Valid \\
\hline & $\mathrm{X} 2.5$ & 0.796 & Valid \\
\hline & X2.6 & 0.752 & Valid \\
\hline & $\mathrm{X} 2.7$ & 0.815 & Valid \\
\hline & $\mathrm{X} 2.8$ & 0.815 & Valid \\
\hline & X2.9 & 0.803 & Valid \\
\hline \multirow{15}{*}{$\mathbf{Y}$} & Y1 & 0.777 & Valid \\
\hline & Y10 & 0.797 & Valid \\
\hline & Y11 & 0.721 & Valid \\
\hline & Y12 & 0.774 & Valid \\
\hline & Y13 & 0.779 & Valid \\
\hline & Y14 & 0.736 & Valid \\
\hline & Y15 & 0.843 & Valid \\
\hline & Y2 & 0.842 & Valid \\
\hline & Y3 & 0.775 & Valid \\
\hline & Y4 & 0.761 & Valid \\
\hline & Y5 & 0.814 & Valid \\
\hline & Y6 & 0.787 & Valid \\
\hline & Y7 & 0.783 & Valid \\
\hline & Y8 & 0.813 & Valid \\
\hline & Y9 & 0.736 & Valid \\
\hline
\end{tabular}

Sumber : Data diolah peneliti, 2021 
Tabel 1.2 Uji Validitas Diskriminan

\begin{tabular}{|c|c|c|c|}
\hline Variabel & AVE & $\sqrt{ }$ AVE & Keterangan \\
\hline $\mathrm{X} 1$ & $\mathbf{0 . 6 6 0}$ & $\mathbf{0 . 6 6 0}$ & VALID \\
\hline $\mathrm{X} 2$ & $\mathbf{0 . 6 1 6}$ & $\mathbf{0 . 6 1 6}$ & VALID \\
\hline $\mathrm{Y}$ & $\mathbf{0 . 6 1 4}$ & $\mathbf{0 . 6 1 4}$ & VALID \\
\hline
\end{tabular}

Sumber : Data diolah peneliti, 2021

Tabel 1.3 Uji Reliabilitas

\begin{tabular}{|c|c|c|c|c|c|}
\hline & $\begin{array}{c}\text { Cronbach's } \\
\text { Alpha }\end{array}$ & rho_A & $\begin{array}{c}\text { Reliabilitas } \\
\text { Komposit }\end{array}$ & $\begin{array}{c}\text { Rata-rata } \\
\text { Varians } \\
\text { Diekstrak } \\
\text { (AVE) }\end{array}$ & Keterangan \\
\hline X1 & 0.897 & 0.898 & 0.921 & 0.660 & VALID \\
\hline X2 & 0.922 & 0.922 & 0.935 & 0.616 & VALID \\
\hline Y & 0.955 & 0.956 & 0.960 & 0.614 & VALID \\
\hline
\end{tabular}

Sumber : Data diolah peneliti, 2021

Tabel 1.4 Adjusted Q-Square

\begin{tabular}{|c|c|c|}
\hline & Q Square & Adjusted Q Square \\
\hline $\mathbf{Y}$ & 0.931 & 0.930 \\
\hline
\end{tabular}


Dapat kita ketahui bahwa kriteria pengujian telah menyebutkan: jika T-Statistic lebih besar daripada nilai $\mathrm{T}$-tabel, maka dinyatakan terdapat pengaruh antara variabel eksogen dengan variabel endogen pada setiap hipotesis yang telah di pakai dalam penelitian. Berdasarkan hasil klasifikasi koefisien jalur pada tabel di atas, dapat terlihat bahwa jalur yang membentuk hipotesis penelitian ini telah terlihat besaran dan juga tingkat signifikansinya.

1. Pengujian Hipotesis Pertama (H1)

Hipotesis pertama menyatakan bahwa Inklusi Keuangan (X1) berpengaruh positif dan signifikan terhadap Kinerja UMKM (Y). Hasil menunjukkan bahwa variabel Inklusi keuangan (X1) memiliki nilai T-statistik sebesar 3,168 dengan p-value sebesar 0,002. Sedangkan untuk nilai T-tabel diketahui -sebesar 1,985 dan p-value lebih kecil dari 0,05 dengan nilai asli positif yang diketahui sama dengan 0,225. Hal tersebut menunjukkan bahwa variabel Inklusi keuangan (X1) secara langsung memiliki pengaruh signifikan dan positif terhadap Kinerja UMKM (Y) sehingga Hipotesis pertama diterima.

2. Pengujian Hipotesis Kedua $(\mathrm{H} 2)$

Hipotesis kedua menyatakan bahwa Literasi keuangan (X2) memiliki pengaruh Positif dan signifikan terhadap Kinerja UMKM (Y). Hasil menunjukkan bahwa variabel Literasi keuangan (X2) memiliki nilai T-statistik sebesar 11,203 dengan p-value sebesar 0,000. Sedangkan nilai Ttabel memiliki nilai sebesar 1,985 dan nilai $p$-value lebih besar dari 0,05 dengan nilai asli 0,756. Hal tersebut menunjukkan bahwa variabel Literasi keuangan (X2) berpengaruh secara positif dan signifikan terhadap Kinerja UMKM (Y). Berdasarkan hal tersebut, maka dapat disimpulkan bahwa untuk hipotesis kedua diterima.

\section{Variabel Inklusi Keuangan berpengaruh Positif dan Signifkan Terhadap Kinerja UMKM}

Berdasarkan hasil pengujian yang telah dilakukan dengan menggunakan software Smart-PLS menunjukkan bahwa untuk Hipotesis pertama (H1) yang menyatakan bahwa Inklusi Keuangan (X1) berpengaruh positif dan signifikan terhadap Kinerja UMKM (Y) adalah diterima. Hasil penelitian menunjukkan bahwa variabel Inklusi Keuangan (X1) yang diwakili oleh dua indicator meiputi: dimensi akses pertanyaan dan dimensi kesejahteraan memiliki pengaruh secara positif dan signifikan terhadap Kinerja UMKM pada Pelaku UMKM dikabupaten Malang. Semakin tinggi inklusi keuangan, maka akan mendorong semakin baiknya kinerja UMKM tersebut.

Dalam Peraturan Presiden Republik Indonesia Nomor 82 Tahun 2016, yamng berisikan tentang Strategi Nasional Keuangan Inklusif, inklusi keuangan merupakan salah satu kondisi dimana pada setiap masyarakat mmeiliki akses dalam berbagai layanan keunagn formal yang berkaulitas, lancar, aman, serta tepat waktu dengan biaya yang terjangkau serta yang sesuai dengan kebutuhan dan kemampuan disetiap anggota masyarakat.

Anwar Prabu Mangkuenegara (2000:67) kinerja merupakan hasil dari kerja secara kualitas dan kuantitas yeng telah dicapai oleh seorang pegawai yang telah melaksanakan tugas sesuai dengan tanggung jawab yang telah diberikan kepada pegawai tersebut. Kinerja merupakan hasil serta fungsi pekerjaan maupun kegiatan individu atau kelompok dalam suatu organisasi yang dipengaruhi dari berbagai faktor guna mencapai tujuan bersama dalam kurun waktu periode yang telah ditentukan. Fungsi dari pekerjaan sendiri adalah pelaksanaan suatu tugas serta kewajiban yang telah diberikan secara individu maupun kelompok karena dengan hal tersebut dapat diselesaikan karena suatu tanggung jawab bersama di dalam suatu kelompok (Tika, 2012:21).

Dalam penelitian sebelumnya yang telah dilakukan oleh Wira Iko Putri Yanti (2019), menyatakan bahwa inklusi keuangan dapat memberikan pengaruh positif dan signifikan terhadap kinerja UMKM. Maka dengan hal ini dapat menunjukkan bahwa kinerja UMKM dapat memberikan peningkatan secara signifikan jika pelaku UMKM dapat memberikan peningkatan dalam inklusi keuangan. Hal ini sejalan dengan hasil yang telah diperoleh peneliti yang juga menyatakan bahwa inklusi keuangan memberikan pengaruh poitif dan signifikan terhadap Kinerja UMKM.

\section{Literasi Keuangan berpengaruh Positif terhadap Kinerja Keuangan}


Berdasarkan hasil pengujian yang telah dilakukan dengan menggunakan software Smart-PLS menunjukkan bahwa untuk Hipotesis pertama (H2) yang menyatakan bahwa Literasi Keuangan (X2) berpengaruh positif dan signifikan terhadap Kinerja UMKM (Y) adalah diterima. Hasil penelitian menunjukkan bahwa variabel Literasi Keuangan (X2) yang diwakili oleh tiga indicator meiputi: dimensi pengetahuan, dimensi perilaku dan dimensi sikap memiliki pengaruh secara positif dan signifikan terhadap Kinerja UMKM pada Pelaku UMKM dikabupaten Malang. Semakin tinggi dan baik pemahaman tentang literasi keuangan, maka akan mendorong semakin baiknya kinerja UMKM tersebut.

Menurut pendapat Hudson dan Bush (Widiyati, 2017), literasi keuangan merupakan suatu kemampuan dalam mamahami suatu kondisi keuangan serta konsep keuangan dan untuk untuk merubah pengetahun dengan baik kedalam suatu perilaku. Literasi keuangan sendiri dapat diartikan sebagai pengetahuan keuangan yang digunakan secara individu guna mengambil suatu keputusan yang dapat meningkatkan suatu perekonomian.

Anwar Prabu Mangkuenegara (2000:67) kinerja merupakan hasil dari kerja secara kualitas dan kuantitas yeng telah dicapai oleh seorang pegawai yang telah melaksanakan tugas sesuai dengan tanggung jawab yang telah diberikan kepada pegawai tersebut. Kinerja merupakan hasil serta fungsi pekerjaan maupun kegiatan individu atau kelompok dalam suatu organisasi yang dipengaruhi dari berbagai faktor guna mencapai tujuan bersama dalam kurun waktu periode yang telah ditentukan.fungsi dari pekerjaan sendiri adalah pelaksanaan suatu tugas serta kewajiban yang telah diberikan secara individu maupun kelompok karena dengan hal tersebut dapat diselesaikan karena suatu tanggung jawab bersama di dalam suatu kelompok (Tika, 2012:21).

Perlunya memiliki cara yang strategis untuk meningkatkan kinerja yakni dengan salah satunya yaki adanya literasi keuangan, keyakinan serta ketrampilan dapat mempengaruhi perilaku serta sikap dalam meningkatkan suatu kualitas dalam pengambilan keputusan serta pengelolaan keunagan untuk mencapai suatu kesejahteraan, hal ini dinyatakan oleh (Ariwibawa D., 2016). Hasil penelitian yang telah dipaparkan oleh Aryo Prakoso (2020), menyatakan bahwa literasi keuangan memiliki pengaruh yang signifikan terahadap kinerja UMKM. Hasil penelitian tersebut mendukung hasil penelitian yang dilakukan oleh peneliti yang menyatakan bahwa literasi keuangan memiliki pengaruh yang positif dan signifikan terhadap Kinerja UMKM.

\section{KESIMPULAN}

Berdasarkan hasil penelitian dan analisis yang sudah dilakukan sebelumnya tentang pengaruh Inklusi keuangan dan Literasi keuangan terhadap Kinerja UMKM pada masa pandemic Covid-19 (Studi kasus pada UMKM Kabupaten Malang), diperoleh hasil kesimpulan sebagai berikut:

1. Inklusi keuangan memberikan pengaruh poitif dan signifikan terhadap Kinerja UMKM pada masa pandemic Covid-19 di UMKM Kabupaten Malang. Artinya semakin baik inklusi keuangan yang dilakukan oleh pelaku UMKM di kabupaten malang misal dengan memberikan inovasi terhadap penggunaan produk dan layanan jasa keuangan UMKM, maka akan meningkatkan citra baik dari Kinerja UMKM tersebut.

2. Literasi keuangan memberikan pengaruh poitif dan signifikan terhadap Kinerja UMKM pada masa pandemic Covid-19 di UMKM Kabupaten Malang. Artinya semakin baik pemahaman terkait dengan literasi keuangan maka akan menambah citra baik terhadap Kinerja dari sebuah UMKM.

\section{DAFTAR USTAKA}

A.A. Anwar Prabu Mangkuenegara, 2000, Manajemen Sumber Daya Manusia, Bandung. PT, Remaja Rosdakarya.

Abor, J., dan P. Quartey. 2010. Issues in SME development in Ghana and South Africa. International Research Journal of Finance and Economics. 39 (6). 219-227. 
Anwar Prabu Mangkunegara (2000). Manajemen Sumber Daya Manusia Perusahaan. Bandung : Remaja Rosdakarya.

Aribawa. 2016. Pengaruh Literasi Keuangan Terhadap Kinerja dan Keberlangsungan UMKM Di Jawa Tengah. E-Jurnal UAJY, 20 (1) : 1 - 13

Huston, S, J. (2010). Measuring financial literacy. Journal of Consumer Affairs, Vol. 44(22), 296-316. https://doi.org/10.1111/j.1745-6606.2010.01170.x

Iko Putri Yanti, W. (2019). PENGARUH INKLUSI KEUANGAN DAN LITERASI KEUANGAN TERHADAP KINERJA UMKM DI KECAMATAN MOYO UTARA . Jurnal Manajemen Dan Bisnis, 2(1).

Mustaqim, Muhamad. (2018). Pengembangan Ekonomi Kreatif Desa. 267-283

Sugiyono. (2018). Metode Penelitian Bisnis (Pendekatan Kuantitatif, Kualitatif, Kombinasi dan R\&B). Bandung: Alfabeta.

Sugiyono (2015). Metode Penelitian Kombinasi (Mix Methods). Bandung: Alfabeta

Soderberg, Johanna. (2013). Functional properties of Legume Proteins Compared to Egg proteins and Their Potential as Egg Replacers In Vegan Food.Faculty of Natural Resources and Agricultural Sciences Department of Food Science.

Tika, Moh. Pabundu. 2012. Budaya organisasi dan peningkatan kinerja perusahaan. Jakarta: BumiAksara

Vitt, L. A., et al. (2000). Personal finance and the rush to competence: Financial literacy education in the U.S. Virginia: Institute for Socio-Financial Studies 